\title{
ECONOMIC AND STATISTICAL ANALYSIS OF SMALL BUSINESS AND PRIVATE ENTREPRENEURSHIP IN THE REGIONS OF THE REPUBLIC OF UZBEKISTAN
}

\author{
Sharipov Bobur Anvar o'g'li \\ Institute for Staff Advanced Training and Statistical Research \\ Researcher, Tashkent, Uzbekistan
}

ABSTRACT

DOI No: 10.36713/epra7962

Article DOI URL: https://doi.org/10.36713/epra7962

The article considers the ways of development of small business and private entrepreneurship in our country using foreign experience, as well as the state of statistics of these forms of management, which occupy a special place in increasing the investment potential of the national economy of different countries.

KEYWORDS: entrepreneurship, private entrepreneurship, business, small business, competitiveness, competitiveness, restructuring, small enterprise, microfirms, small business shares, innovation activity

\section{INTRODUCTION}

Small business and private entrepreneurship are an important factor in economic development, employment and income. Over the past two and a half years, more than fifty decrees and resolutions of the President of the Republic have been adopted to provide comprehensive support to the representatives of this sphere. Based on them, the procedures for state registration of business activities, obtaining various permits and many other services have been simplified. To facilitate this, the Public Service Agency and its local centers have been established. The position of Representative (Business Ombudsman) for the protection of the rights and legitimate interests of business entities was introduced. In addition, Prime Minister's receptions have been set up in all regions to receive and resolve complaints from entrepreneurs. The State Fund for Entrepreneurship Development under the Cabinet of Ministers has been set up and allocated 200 billion soums and $\$ 50$ million. The volume of loans provided by commercial banks to entrepreneurs has increased.

Opportunity to establish small business and private entrepreneurship in the country - mass initiatives are one of the necessary conditions for the successful development of these forms of management. Small business and private entrepreneurship is, first and foremost, an institution that employs the population and creates conveniences for its activities. Through the development of small business and private entrepreneurship, it is possible to solve the problems associated with ensuring economic growth and the transition to the path of innovative development. Small business and private entrepreneurship have the potential to emerge from the crisis, expand mobility and flexibility for small and medium-sized companies, mitigate negative processes in employment, ensure their social adaptation and create jobs in large enterprises, as well as create new markets and significantly contributes to economic growth. 
The current statistical situation and development of small business and private entrepreneurship in our country is a topical issue.

Determining the main directions and methods of assessing the state of small business and private entrepreneurship, the organization of statistical data collection on small business and private entrepreneurship, the main indicators of statistical data collection, the main criteria for determining small business statistics, as well as world rankings should be used. Based on these requirements, the study summarized the international requirements, identified the main directions and methods of collecting statistics on this category of entities to assess the state of small business in the country.

In the modern economic environment, the role of entrepreneurship in economic development is increasingly being discussed, and the development of statistical methodologies for measuring and researching entrepreneurship is becoming a priority for many statistical agencies and international organizations. Without statistics on small business and private entrepreneurship, it is impossible to obtain accurate quantitative characteristics of the market situation and to carry out their research and forecasts. Any small business and private entrepreneurship can be seriously harmed if they do not understand the statistical structure of small business and private entrepreneurship statistics and do not conduct statistical research on the quantitative characteristics of the market [7].

Only the use of methods of processing statistical indicators, various data on the business environment should be the basis for a better understanding of the development processes of economic policy and the development of appropriate forms of management, the assessment of its prospects. A comparative statistical data system and a reliable database are a necessary condition for assessing the state of small business in the country and determining the direction of the policy of state support of small business [8].

In our country, a number of measures are being taken to support small business and private entrepreneurship by the state (Figure 1). The functions of small business and private entrepreneurship statistics include [9]:

- Development of methods and tools (forms of monitoring, instructions for their completion) for the organization and conduct of statistical monitoring of small business and private entrepreneurship;

- introduction of methods of observation of small business and private entrepreneurship in statistical practice, continuous improvement of its programs and methods;

- $\quad$ organization, development and improvement of methods of registration of small business and private entrepreneurship;
- formation of a general set of statistical monitoring objects, including all registered small businesses and private entrepreneurship entities;

- creation of a database for identification and additional calculation of performance of small business and private entrepreneurship;

- Development of a system of statistical indicators describing the activities of small businesses and private entrepreneurship by type of economic activity, administrative-territorial structures;

- determining the role of small business and private entrepreneurship in the country's economy;

- Identification of resource potential and statistical assessment of the effectiveness of small business and private entrepreneurship.

Collection of statistics on the activities of small businesses and private entrepreneurship requires special criteria for their identification. The priorities of short-term planning, the special role of the entrepreneur in the production process (both owner and manager), the organization of production, the qualitative characteristics of which he finances his own funds (medium, large, small business) are known. However, for statistical research and small business development forecasts, only quantitative indicators can be used, using only qualitative criteria [6].

Statistics of small business and private entrepreneurship are used by government agencies, business associations, research organizations for the following purposes:

1) to compile the results of economic activity at the macroeconomic level, calculations of the main aggregates and forecasts of economic development;

2) definition of the state policy in the field of support of small business;

3) taxes and fees for the purpose of planning revenues to the state budget.

In international statistical practice, there are no single international criteria for measuring small businesses. The concept of "small business" is applied in each country depending on the structure of the economy of that country and the legal documents governing small business. For example, the term "small business" or "small business enterprise" is common in the United States and the United Kingdom, while the term "small and medium enterprise" is frequently used in a number of Western European countries and Japan. In EU countries, small and medium enterprises are divided into medium and small enterprises [3].

An analysis of the state of development of small and medium-sized enterprises in the field of entrepreneurship shows that the number of small and medium enterprises per 1,000 population, for example, in the United States is 20, while the share of small and medium enterprises in GDP is $62 \%$. The 
figure is 33 percent and 27 percent in Canada, 40 percent and 35 percent in Australia, 45 percent and 55 percent in Japan, 21 percent and 47 percent in Malaysia, 85 percent and 35 percent in the Czech
Republic, 55 percent and 50 percent in Hungary, 27 percent and 53 percent in the United Kingdom. and 39 percent and 21 percent in Russia (Table 1).

Table 1

Indicators of the level of development of small and medium enterprises in the field of entrepreneurship in different countries [10] (as of January 1, 2019)

\begin{tabular}{|c|c|c|c|}
\hline Countries & $\begin{array}{c}\text { Number of small and } \\
\text { medium enterprises per } \\
\mathbf{1 , 0 0 0} \text { population }\end{array}$ & $\begin{array}{c}\text { Percentage of people } \\
\text { employed in small and } \\
\text { medium enterprises, } \%\end{array}$ & $\begin{array}{c}\text { Contribution of small } \\
\text { and medium enterprises } \\
\text { to GDP, } \%\end{array}$ \\
\hline United States & 20 & 42 & 52 \\
\hline Canada & 33 & 47 & 27 \\
\hline Australia & 40 & 69 & 35 \\
\hline Japan & 45 & 77 & 55 \\
\hline Malaysia & 21 & 56 & 47 \\
\hline Russia & 39 & 43 & 21 \\
\hline Czech Republic & 85 & 51 & 35 \\
\hline Hungary & 55 & 48 & 50 \\
\hline United Kingdom & 27 & 35 & 53 \\
\hline
\end{tabular}

In the UK, statistical agencies operate in a decentralized manner, collecting statistical data by industry departments that are closely linked to the activities of the relevant administrative bodies. There is an agreement on the exchange of statistical information between the departments. The main advisory and coordinating body in this regard is the Central Statistics Office, which maintains regular contacts with all departments.

In Japan, too, the statistical organization is decentralized, with each ministry having statistical offices, departments, or divisions. Statistical work is carried out by the heads of prefectures, mayors, administrative centers and rural settlements. In each prefecture, the statistician performs the functions of the Central State Apparatus and the administration of the prefecture. The Central Statistical Institute of Japan is a statistical commission that deals with the standardization and coordination of statistical work, statistical data analysis, training, and international statistical activities.

The central statistical body in France is the National Institute of Statistics and Economic Research. It regularly provides the government and the monopoly with detailed statistics, while the regional statistical offices perform nationwide tasks and conduct regional demographic and economic surveys. The National Institute of Statistics and Economic Research annually inspects more than 7,000 industrial enterprises, periodically inspects and monitors trade, transport and consumer services enterprises.

In Canada, data collection across the country is carried out by the Bureau of Statistics in collaboration with local authorities. There are eight regional agencies involved in the collection and dissemination of statistics that conduct special surveys. Inspection plans, results are processed and published by the Bureau of Statistics. Industrial enterprises are usually inspected by e-mail survey.

The Statistical Office of the European Union is responsible for the preparation of statistical data on EU member states and the harmonization of statistical methods used by these countries.

Duties of the Statistical Service of the European Union:

Development of statistical infrastructure;

General expansion of statistical activity;

creation of a single integrated European statistical system;

Development and use of a single methodology and statistical standards to achieve comparability and reliability of statistical data;

Providing the EU with high quality statistics;

Comparison between EU member states and other countries and regions;

Considered important economic decisions at the European level [6].

Although many countries do not have targeted programs for collecting business statistics, they are based on aggregated data on different aspects of the business environment at the national level (e.g., selfemployment, business demographics, and rarely, individuals and businesses or businesses from different sources). indicators) monitoring statistics are available [8].

An in-depth analysis of the content and characteristics of international databases of business indicators developed outside statistical offices shows that there are various methodological and conceptual problems that cast doubt on their usefulness as a reliable basis for policy development. The main problems are: 
Doubts about data quality (reliability of data samples or sources);

Restriction of collection of indicators on certain legal forms of enterprises;

Limiting data collection by individuals only (although individual inquiries may provide extensive information about the future characteristics of entrepreneurs or entrepreneurs, the actual efficiency of established enterprises remains outside the scope of coverage).

Monitoring of the state of small business involves the comparison of statistical, natural and financial indicators, as well as a set of analytical materials describing the state of the sector on the exact date for the period under analysis. In this case, one of the tools to determine the level of development of small business and private entrepreneurship is statistics. In such cases, some measurements that may be useful (industrial production, labor productivity, etc.) are often not made. Sometimes different evaluation methods are used, including quantitative and qualitative analysis methods, as well as world ranking data [4].

For statistical assessment of the state of small business, its role in the development of the economy of the country and regions, it is necessary to form a system of indicators consisting of:

- number of small business entities;

- number of small enterprises;

- share of small enterprises in the total number of enterprises;

- distribution of small enterprises by industries;

- Number of small businesses per 1,000 people, revenue from product sales;

- value of assets of small enterprises, value of fixed assets of small enterprises;

- financial results: labor productivity, gross income, sales revenue;

- net profit, the amount of income received per worker per year;

- Determining the return on assets of small businesses.

Our analysis shows that the share of small business and private entrepreneurship in GDP increased from $45.7 \%$ in 2007 to $56.5 \%$ in 2019 . The status of the share of this category of entities in the economy in industry, construction, employment, exports, imports, trade, agriculture, forestry and fisheries and services was also studied (Table 2).

Table 2

The share of small business and private entrepreneurship in the economy of Uzbekistan in 2007-2019

[11].

(in\% of total volume)

\begin{tabular}{|c|c|c|c|c|c|c|c|c|c|}
\hline$\stackrel{\mathscr{J}}{\stackrel{\mathscr{J}}{む}}$ & )ิ & 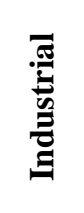 & 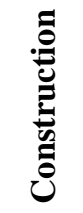 & 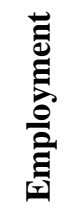 & 离 & & تِّ & 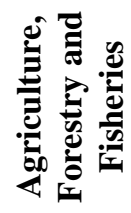 & : \\
\hline 2007 & 45,7 & 13,2 & 55,4 & 72,1 & 14,8 & 32,0 & 87,8 & 97,6 & 44,1 \\
\hline 2008 & 48,2 & 14,6 & 58,4 & 73,1 & 12,4 & 35,7 & 84,6 & 97,7 & 44,2 \\
\hline 2009 & 50,1 & 17,9 & 42,4 & 73,9 & 14,6 & 42,5 & 81,0 & 97,8 & 44,1 \\
\hline 2010 & 52,5 & 26,6 & 52,5 & 74,3 & 13,7 & 35,8 & 85,1 & 97,4 & 56,1 \\
\hline 2011 & 54,0 & 28,6 & 67,6 & 75,1 & 18,8 & 34,3 & 86,7 & 97,2 & 55,6 \\
\hline 2012 & 54,6 & 29,7 & 70,0 & 75,6 & 14,0 & 38,6 & 87,3 & 97,2 & 56,0 \\
\hline 2013 & 55,8 & 33,0 & 70,6 & 76,7 & 26,2 & 42,4 & 86,6 & 97,3 & 56,2 \\
\hline 2014 & 56,1 & 36,8 & 69,5 & 77,6 & 27,0 & 45,4 & 86,3 & 97,5 & 59,1 \\
\hline 2015 & 62,9 & 40,6 & 66,7 & 77,9 & 27,0 & 44,5 & 87,1 & 98,0 & 60,2 \\
\hline 2016 & 64,9 & 45,3 & 66,9 & 78,2 & 26,0 & 46,8 & 89,6 & 98,6 & 63,2 \\
\hline 2017 & 63,6 & 41,2 & 64,8 & 78,0 & 22,0 & 53,6 & 88,4 & 98,5 & 58,3 \\
\hline 2018 & 59,4 & 37,4 & 73,2 & 76,3 & 27,2 & 56,2 & 86,3 & 98,3 & 56,0 \\
\hline 2019 & 56,5 & 25,8 & 75,8 & 76,2 & 27,0 & 61,6 & 83,6 & 97,9 & 53,2 \\
\hline
\end{tabular}

Entrepreneurship is not only the basis for the development of competitive relations, but also a means of solving the problems of employment, innovation and economic growth. However, there are still no general approaches to assessing entrepreneurship (including assessing the level of entrepreneurial activity). Assessment of business development can be done only on the basis of a comprehensive statistical approach, using existing statistics, world rankings, taking into account the qualitative and quantitative characteristics.

Indicators of investment activity of small enterprises are as follows:

- fixed capital investments;

- $\quad$ share of investments in fixed assets of the region;

- ratio of investments in fixed assets;

- $\quad$ Net profit to investment ratio. 
In 2019, the total number of newly established small enterprises and micro-firms in the regions will be Tashkent (19.6\%), Tashkent (10.5\%), Samarkand $(8.6 \%)$, Navoi $(7.6 \%)$, Fergana $(7,2 \%)$, Bukhara $(6.6 \%)$, Namangan $(5.8 \%)$, Kashkadarya $(5.5 \%)$, Khorezm (5.1\%) regions, the Republic of Karakalpakstan $3.9 \%)$, Jizzakh $(3.7 \%)$ and the lowest in Syrdarya region $(3.4 \%)$.

The contribution of small business to the socio-economic development of the regions is determined by the following indicators:

- number of employees;

- share of employees in the total number of employees operating in the region;

- $\quad$ staff salary fund;

- $\quad$ average salary of the employee;

- total share in the gross regional product;

In order to create new jobs in the process of modernization of the economy, it is necessary to further improve the provision of new, modern banking services to small businesses and private entrepreneurship.

In order to improve small business and private entrepreneurship in our country, it is necessary to:

At first, small business and private entrepreneurship, processing of agricultural products, as well as improving the creation of new jobs in the service sector, further development of family business, development of services, especially in rural areas, further expansion of home-based activities, with their large enterprises it is necessary to increase the number of joint ventures;

second, to further strengthen the legal framework that protects the interests of private property, private entrepreneurs; the norms of legal protection of the rights and guarantees of small business and private entrepreneurs should be strengthened;

third, simplification of the mechanism of use of raw materials by private entrepreneurs, for which it is necessary to expand the volume of sales of resources at open exchanges and fairs;

fourth, to increase employment through the development of small and private entrepreneurship, it is necessary to determine the local mineral resources, material and technical and labor resources, domestic market capacity, processing capacity of agricultural products in each district and city;

fifth, to continue the process of providing private entrepreneurs with microcredits, with extensive use of funds from commercial banks and extra-budgetary funds in the country;

sixth, it is necessary to continuously develop small business and private entrepreneurship, which will increase the demand for labor and reduce unemployment;

seventh, it is necessary to further improve the process of obtaining microcredits for folk craftsmen and masters to expand the workshops and organize new ones in a modern look;

eighth, it is necessary to improve the attraction of soft credit resources to finance projects that create new jobs in remote rural areas.

The experience of developed countries shows that it is successfully developing with the direct participation of government agencies in the development and implementation of policies to support small and medium-sized businesses. It is especially important to support small and mediumsized innovative enterprises as the most sensitive to changes in the external environment, taking into account the most dangerous aspects and their specific characteristics.

In short, small business is an integral element of a modern market management system. Without it, the economy and society in general cannot exist and develop. Independent entrepreneurs are the largest stratum of private property owners, and due to this aspect they play an important role not only socioeconomically, but also in the political life of the country. Depending on their economic status and living conditions, private entrepreneurs form the basis of the middle class, which guarantees the social and political stability of society..

\section{REFERENCES}

1. Smith. A An Inquiry into the Nature and Causes of the Wealth of Nations. $\quad-M ., 2017.359$ p.

2. Komarova O.V. Problems of the development of handicrafts, small and medium business and the middle class: monograph // O.V. Komarova, T.A. Salamatova, D.E. Gavrilov. Yekaterinburg: Publishing house Ros. state prof. - ped. University, 2012. -163 p.

3. Abdullaev Yo. Basics of Small Business and Entrepreneurship Part 1100 questions and 100 answers. - T .: Mehnat, 2000. $-352 p$.

4. Shodiev H., Hamroev M. Financial Statistics / Textbook - T .: Abu Ali Ibn Sino Medical Publishing House, 2002. -236 p.

5. Course sotcial-economical statistics; under the editorship of Doctor of Economic Sciences, Professor M.G. Nazarova.-, 2000. -324 p.

6. United States Small Business Profile 2018. SBA, 2018, pp. 5-6.

7. Data of the State Statistics Committee of the Republic of Uzbekistan. www.stat.uz

8. www.kitobxon.uz

9. www.lex.uz 